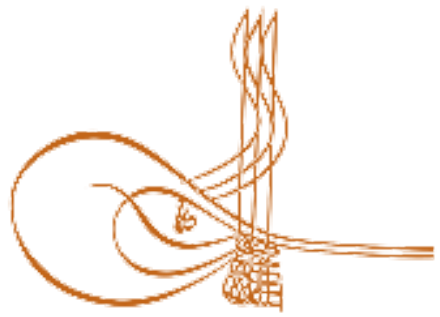

www.turkishstudies.net/language
Turkish Studies - Language and Literature

eISSN: $2667-5641$

Research Article / Araștırma Makalesi

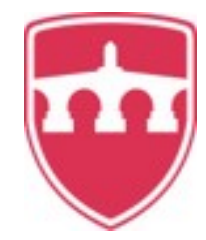

INTERNATIONAL

BALKAN

UNIVERSITY

Sponsored by IBU

\title{
Çeviri Teknolojileri, Yerelleştirme Konulu Lisansüstü Tezlerin Türkçe Çeviribilim Literatürü Bağlamında Değerlendirilmesi
}

\author{
Evaluation of Graduate Theses on Translation Technologies and Localization within the Context of \\ Turkish Translation Studies Literature
}

\author{
Ceylan Yıldırım*
}

\begin{abstract}
This study focuses on graduate theses on translation technologies and localization, which are prepared in translation-interpreting and translation studies programs in Turkish universities, within the context of contemporary literature on Turkish translation studies. The aim of this study is to clarify the gaps in the academic literature on Turkish translation studies, to be filled by graduate theses on translation technologies and localization, and to make some suggestions for existing shortcomings. Which sub-fields are discussed in those graduate theses through their specific field of study? What is the extent of adequacy in translation technologies and localization topics, examined in terms of translation studies' applied and theoretical areas? Which new and unexplored subjects are covered by the graduate theses' scopes in the specified field of the Turkish translation studies literature? In this study, through descriptive approach, the theses on translation technologies and localization, prepared in translation-interpreting or translation studies programs in Turkey, are examined in detail. As the particular outcome of this study, that theses within the above-mentioned scope have contributed the field of translation technologies and increased its prominence, graduate theses on Turkish translation studies literature have contributed to and increased the quality and quantity of Turkish sources in this field. However, increasing number of graduate theses in translation technologies, which is one of the research fields in translation science, carrying analysis further in the theoretical context of translation science, and selecting the thesis research subjects within the framework of new orientations; all these will play an important role in filling other specific gaps in Turkish translation studies literature. It is hoped that this study will contribute to translation studies field and to researchers, academics and students who are particularly interested in translation.
\end{abstract}

Structured Abstract: This study, analysing and evaluating graduate theses on translation technology and localization prepared in translation-interpreting and translation studies programs in Turkish universities is distinguished from other studies by its subject. The following questions are tried to be answered in this study including a detailed analyse of graduate theses on translation technologies and localization in Turkey within

\footnotetext{
* Dr. Öğr. Üyesi, Hacettepe Üniversitesi, Edebiyat Fakültesi, Mütercim-Tercümanlık Bölümü

Assist. Prof. Dr., Hacettepe University, Faculty of Letters, Departement of Translation and Interpreting ORCID 0000-0001-8456-0299

ceylany@hacettepe.edu.tr
}

Cite as/ Atıf: Yıldırım, C. (2020). Çeviri teknolojileri, yerelleştirme konulu lisansüstü tezlerin Türkçe çeviribilim literatürü bağlamında değerlendirilmesi, Turkish Studies - Language, 15(1), 497-514. https://dx.doi.org/10.29228/TurkishStudies.39592

Received/Gelis: 04 November/Kasim 2019

Accepted/Kabul: 24 March/Mart 2020

Copyright (C) INTAC LTD, Turkey 
the framework of descriptive approach: What are the graduate theses topics on translation technology and localization prepared in the translation-interpreting or translation studies programs in Turkey? Which gaps are filled in Turkish translation studies literature by these theses? What are the other gaps that need to be filled in the Turkish translation studies literature on the subject of translation technologies and localization and which sub-topics can be proposed in this context? Within the framework of the descriptive approach adopted in the study, in the light of the data obtained from the detailed analysis of the documents, it has been revealed which gaps are filled in the Turkish translation studies literature on the translation technologies subfield.

In the first part of the study, theses on translation technology and localization prepared in translation-interpreting or translation studies programs in Turkey have been identified by National Thesis Center database in Turkey. As a result of the research, it was understood that 9 of the 16 graduate theses were master's theses, 7 of them were doctoral theses and 15 of these theses were prepared in Turkish. Only one of the theses is in English. This finding points to an effort to develop and enrich Turkish translation technologies literature. It was seen that 7 of the 16 graduate theses were prepared in Sakarya University and 4 of the 7 doctoral dissertations were prepared in Sakarya University. This finding indicates that Sakarya University has a leading position in our country in terms of contributing to the field of translation technologies and the literature of Turkish translation technologies. It was found that 3 graduate theses are in preparation on this subject and 2 of these theses are in English language and 1 of them is in Turkish language. This situation was evaluated as a negative development in terms of not providing Turkish sources to the Turkish translation studies literature on the subject. Preparation of graduate theses on translation technologies in other Turkish universities that have not previously conducted thesis studies in this field has been evaluated as a positive development. In additon, the rapid increase in the number of doctoral theses prepared since 2014 and the emphasis on localization in these doctoral theses point to an effort to fill the gaps in the Turkish translation studies literature.

In the second part of the study, the graduate theses in the scope of the subject are examined in detail and the gaps filled by these theses in Turkish translation studies literature are revealed and evaluated in terms of their contribution to the field. As a result of this study, it was seen that translation technologies and localization were partly discussed in terms of the applied and theoretical areas of translation studies. In general, theses on translation technologies and localization have addressed previously the topics not been discussed before in Turkey and priority has been given to the lacking issues in Turkish translation studies literature. In this context, the position of translation technologies and localization in translation education and in the translation market has been revealed through surveys with students, translators, sector stakeholders and academician views. The position of translation technologies in translation education has been revealed by questionnaires, curriculum analyzes or academician views, but it has not been adequately questioned whether the translation technologies courses are handled in accordance with the course content. In this context, studies should be carried out to determine whether the necessary technical conditions (equipment and materials) and expert personnel are provided for the conduct of the courses in accordance with their contents.

Besides, for the effective use of translation technologies in translation education, thesis studies can be encouraged to offer educational model proposals about the arrangement of some other translation courses to include translation technologies. However, it is seen that there is not enough number of graduate theses studies in which translation technologies and localization are handled in terms of theoretical field of translation studies. Increasing the studies in this direction will contribute to the development of the theoretical field of translation studies. As a result, the studies on localization in the context of translation studies, Turkish theses on post-editing, the studies dealing with machine translation in the context of translation studies, the studies for the production and evaluation of CAT tools, the studies on artificial intelligence in the context of translation studies, the studies on the relationship between the translation technologies and IT in the context of translation studies should be increased. In addition, it will contribute to the development of the field of translation studies by focusing on thesis studies on the relationship between translation technologies and other research topics of translation studies. Preparing theses on translation technologies and localization in all universities in Turkey that have master or doctorate program in translation studies will contribute to both the development of the field and the enrichment of Turkish translation studies literature.

As a conclusion, graduate theses prepared on translation technologies and localization in translationinterpreting or translation studies programs in Turkey, contribute to the developpment and enrichment of 
Turkish translation studies literature. However, to focus on the new developments in the field of translation technologies will contribute to our progress in parallel with international translation studies literature.

Keywords: Translation Studies, Turkish Translation Studies Literature, Translation Technologies, Localization, Graduate Theses.

Öz: Bu çalışmada, Türkiye'deki mütercim-tercümanlık veya çeviribilim bölümlerinde hazırlanan çeviri teknolojileri, yerelleştirme konulu lisansüstü tezler, Türkçe çeviribilim literatürü bağlamında değerlendirilmektedir. Çalışmanın amacı, Türkiye'de hazırlanan çeviri teknolojileri, yerelleştirme konulu lisansüstü tezlerin, Türkçe çeviribilim literatüründe hangi boşlukları doldurduğunu açığa çıkarmak ve mevcut eksikliklerin giderilmesi için bazı önerilerde bulunmaktır. Türkiye'de konu kapsamında hazırlanan lisansüstü tezler hangi alt başlıklara yönelmektedir? Çeviri teknolojileri, yerelleştirme konusu, çeviribilimin kuram ve uygulama alanları açısından yeterince irdelenmiş midir? Konu kapsamında hazırlanan lisansüstü tezler, Türkçe çeviribilim literatüründeki hangi boşlukları doldurmaktadır? Çalışmada, betimleyici yaklaşım çerçevesinde, Türkiye'deki mütercim-tercümanlık veya çeviribilim bölümlerinde hazırlanan çeviri teknolojileri, yerelleştirme konulu lisansüstü tezler ayrıntılı bir şekilde incelenmiştir. Çalışma neticesinde, Türkiye'de hazırlanan konu kapsamındaki lisansüstü tezlerin, çeviri teknolojileri alt alanının Türkiye'de daha tanınır hale gelmesine, bu alandaki ihtiyaç ve eksiklerin tespit edilmesine, Türkçe çeviribilim literatüründe çeviri teknolojileri, yerelleștirme konusuyla ilgili boşlukların doldurulmasına ve Türkçe kaynak eksikliğinin giderilmesine katkı sağladığı görülmüştür. Bununla birlikte, çeviribilimin araştırma konularından biri olan çeviri teknolojileriyle ilgili lisansüstü tezlerin artırılması, bu tezlerde çeviribilimin kuramsal bağlamının daha fazla ele alınması ve yeni yönelimler çerçevesinde tez konusu seçilmesi, Türkçe çeviribilim literatüründeki diğer boşlukların doldurulmasında önemli bir rol oynayacaktır. Bu çalışmanın, çeviribilim alanına ve çeviriyle ilgilenen araştırmacı, akademisyen ve öğrencilere katkı sağlayacağı ümit edilmektedir.

Anahtar Kelimeler: Çeviribilim, Çeviribilim Literatürü, Çeviri Teknolojileri, Lisansüstü Çeviri Eğitimi, Lisansüstü Tezler, Yerelleştirme.

\section{Giriş}

Teknolojik gelişmelere paralel olarak, çeviribilimin çeviri teknolojileri alt alanı de gelişmektedir. Türkçe çeviribilim literatüründe, çeviri teknolojileriyle ilgili kaynaklar çeviribilimin diğer araştırma alanlarına oranla sayıca az olsa da çeviri teknolojilerini konu alan Türkiye'deki bilimsel çalışmaların sayısında, özellikle 2000'li yıllardan itibaren bir artış yaşandığı gözlemlenmektedir. Şahin, çeviri teknolojilerinin çeviribilim alanındaki yeri ve önemine değindikten sonra, çeviri teknolojileri alanında yapılan çalışmaların sayısında son yıllarda artış yaşandığını şu sözlerle aktarmaktadır:

"Çeviri teknolojileri çeviribilim alanı içinde bir alt alan olarak ortaya çıkarak çeviri alanında hak ettiği yeri almıştır ve bu alt alan çerçevesinde yapılan bilimsel çalışmaların sayısı gün geçtikçe artmaktadır. Hiç şüphe yok ki, yapılan bütün bilimsel araştırmaların uygulamaya, öğretime ve kurama katkısı büyüktür ve hem genel anlamda çeviri teknolojilerinin hem de üzerinde çalışlan dil ve diller için özel hazırlanan araçların gelişimine ve geliştirilmesine ivme kazandırmaktadır... Aynı şekilde Kanada, Almanya, Avustralya, Birleşik Krallık ve Amerika Birleşik Devletleri gibi çokdilli ya da çok kültürlü ülkelerde de genel olarak çeviri ve çeviri teknolojileri konularında yapılan çalı̧̧alar alanın gelişmesi yönünde büyük katkılar sunmaktadır. Ülkemizde de çeviri teknolojileri alanında yapılan çalışmalar son on yılda büyük bir yer tutmaktadır." (Şahin 2013: 143)

Odacioğlu'nun, Atılım Üniversitesi'nde, 2018 yılında sunduğu “Çeviri Teknolojilerinin Çevirmen Adayları İçin Önemi: Kuramsal Bir Bakış" başlıklı bildiride aktardıkları, teknolojinin çeviribilimdeki yeri ve önemine değin bilgi vermektedir: 


\begin{abstract}
"Bugüne gelindiğinde ise çeviribilimin dilsel ve kültürel aktarım kadar bir teknoloji aktarımı olduğu gözlemlenmeye başlamıştır. $O$ halde çeviri sürecinde uzman konumunda itibar edilen ve aldığı kararlara saygı gösterilmesi gereken çevirmenin sahip olduğu dilsel ve kültürel edincin yanı sıra teknoloji edinci de geliştirmesi son derece önem arz etmektedir.” (Odacioğlu 2018: 1)
\end{abstract}

Balkul ve arkadaşları, "Türkiye'de Çeviribilim Alanında 2013-2018 Yılları Arasında Hazırlanan Makaleler Üzerine Betimsel Bir Analiz" başlıklı çalışmalarında, ilgili yıllar arasında hazırlanan makalelerde, çeviribilimin hangi araştırma konularının hangi araştırma yöntemleriyle ele alındığını irdelemiş ve makale sayılarının yıllara göre artış gösterip göstermediği sorgulamışlardır. Çalışmalarında ulaştıkları tespitlerden biri, 2013-2018 yılları arasında Türkiye'de hazırlanan makalelerde, uluslararası çeviribilim literatüründe popüler olan araştırma konularının bolca ele alındığı ve bu bağlamda uluslararası çeviribilim literatürüyle paralel ilerlediğimiz yönündedir. Popüler araştırma konuları arasında çeviri teknolojilerinin de yer alması, bu alt alanın çeviribilimdeki önemine dikkat çekmektedir: "Uluslararası çeviribilim literatüründe popüler olan çeviri teknolojileri, çevirmenlik mesleği ve Çeviri Sosyolojisi gibi araştırma alanlarının ülkemizde yayınlanan makalelerde de bolca ele alınması, ülkemizdeki çeviribilim araştırmalarının uluslararası literatüre paralel ilerlediğini göstermektedir. (Balkul ve Can, Çalık, Gümüş 2018: 288)

Türkiye'deki çeviribilim veya mütercim-tercümanlık bölümlerinde hazırlanan lisansüstü tezlerin incelenmesini kapsayan bazı çalışmalar yapılmıştır. Ersoy ve Balkul'un "Çeviribilim Alanındaki Lisansüstü Tezler Üzerine Betimleyici Bir Çalışma” başlıklı çalışması, "Türkiye'de 2016 yılına kadar çeviribilim alanında lisansüstü düzeyde hazırlanan tezlerin farklı parametreler 1şı̆̆ında incelenmesini ve bunun sonucunda akademik düzeyde çeviribilim araştırmalarının hangi eğilimde olduğunu saptamayı hedeflemektedir" (2016: 152). Yazıcı'nın, "Çeviribilimde Yüksek Lisans Tezleri Üzerine Görgül Bir Araştırma” (2007) başlıklı bir bildirisi bulunmaktadır. Balkul, "Türkiye'de Akademik Çeviri Eğitiminde Çeviri Teknolojilerinin Yerinin Sorgulanması: Müfredat Analizi ve Öğretim Elemanlarının Konuya İlişkin Görüşleri Üzerinden Bir İnceleme" (2015) başlıklı doktora tezinde, "Uluslararası Platformda Çeviri Teknolojileri Alanında Yapılan Çalışmalar" ve "Ülkemizde Çeviri Teknolojileri Alanında Yapılan Çalışmalar" alt başlıklarıyla çeviri teknolojileri alanında yapılan bazı çalışmalara genel hatlarıyla değinmiştir. Balkul, çeviri teknolojileriyle ilgili lisansüstü tezlerden, özellikle kendi konusuyla (çeviri teknolojileri öğretimiyle) ilgili olanlara odaklanmıştır. $\mathrm{Bu}$ nedenle, çalışmasında, konunun sınırlılıkları çerçevesinde, sadece BDÇ alanında hazırlanan bazı lisansüstü tez isimleri -Sinem Canım'ın yüksek lisans tezi, 2008 ve Oğuzhan Atila'nın yüksek lisans tezi, 2013- (Balkul 2015: 47-54) geçmekte olup mütercim-tercümanlık veya çeviribilim bölümlerinde hazırlanan çeviri teknolojileri, yerelleştirme konulu tüm lisansüstü tezler ele alınmamıştır.

Bu çalışma, Türkiye'deki mütercim-tercümanlık veya çeviribilim bölümlerinde hazırlanan çeviri teknolojileri, yerelleştirme konulu lisansüstü tezlerin Türkçe çeviribilim literatürü bağlamında incelenip değerlendirilmesini konu edinmesi bakımından diğer çalışmalardan ayrılmaktadır. Çeviri teknolojileri, yerelleştirme konusunda ülkemizde hazırlanan lisansüstü tezlerin betimleyici yaklaşım çerçevesinde detaylı bir şekilde incelenmesini kapsayan bu çalışmanın sorunsalını şu sorular oluşturmaktadır: Türkiye'deki mütercim-tercümanlık veya çeviribilim bölümlerinde hazırlanan çeviri teknolojileri, yerelleştirme konulu lisansüstü tez başlıkları nelerdir? Konu kapsamındaki lisansüstü tez çalışmaları, Türkçe çeviribilim literatüründeki hangi boşlukları doldurmaktadır? Türkçe çeviribilim literatüründe çeviri teknolojileri, yerelleştirme konusunda doldurulması gereken diğer boşluklar nelerdir ve bu bağlamda, hangi alt konu başlıkları önerilebilir?

Çalışmanın birinci bölümünde, YÖK Ulusal Tez Merkezi veri tabanı aracılığıyla, mütercim-tercümanlık veya çeviribilim bölümlerinde hazırlanan çeviri teknolojileri, yerelleştirme konulu lisansüstü tezler tespit edilerek liste halinde sunulacak ve tezlerin tamamlanma y1l, 
hazırlandığ1 üniversite ve yazıldığı dil göz önünde bulundurularak bir değerlendirme yapılacaktır. Çalışmanın ikinci bölümünde, Türkiye'deki mütercim-tercümanlık veya çeviribilim bölümlerinde hazırlanan çeviri teknolojileri, yerelleştirme konulu lisansüstü tezler detaylı bir şekilde incelenerek Türkçe çeviribilim literatürü bağlamında değerlendirilecektir. Değerlendirme neticesinde, lisansüstü tezlerin, Türkçe çeviribilim literatüründe hangi boşlukları doldurduğu açığa çıkarılacak ve alandaki eksikliklerin giderilmesine nasıl katkı sağladığı değerlendirilmeye çalışılacaktır. Çalışmanın sonuç bölümünde, çalışma boyunca elde edilen bulgular genel hatlarıyla değerlendirilecek ve bazı önerilerde bulunulacaktır.

\section{Türkiye'deki Mütercim-Tercümanlık veya Çeviribilim Bölümlerinde Hazırlanan Çeviri Teknolojileri, Yerelleştirme Konulu Lisansüstü Tezler}

Kapsamlı araştırma gerektiren lisansüstü tezler, ilgili alandaki değişim-dönüşümlere bağlı ihtiyaç ve eksikliklerin giderilmesine katkıda bulunmaktadır. Çeviri teknolojileriyle ilgili lisansüstü tez sayısı, Türkiye'de son yıllarda artış göstermiş olsa da bu sayı çeviribilimin diğer araştırma konularında hazırlanan tez sayılarına göre azdır. Bunun nedeni, çeviri teknolojileri konusundaki çalışmaların, görgül ve ampirik yönteme dayanan araştırmalar gerektirmesine ve lisansüstü eğitimde çeviri teknolojileri alanında uzmanlaşmış öğretim üyesi eksikliğine bağlı olarak açıklanabilir. Ayrıca, yüksek lisans veya doktora düzeyinde çeviri eğitimi veren üniversite sayısının ülkemizde az olmasının, daha spesifik bir araştırma konusu olan çeviri teknolojileriyle ilgili tezlerin sayıca az olmasında etkili olduğu söylenebilir. Ersoy ve Balkul'un, yüksek lisans ve doktora eğitimi veren üniversite sayılarına ilişkin ortaya çıkardıkları aşağıdaki rakamlar, bu etkinin olasılığını güçlendirmektedir:

“Türkiye'de 2016-2017 akademik yılı verileri göz önünde tutulduğunda, farklı yabancı dil seçenekleri ile çeviribilim alanında yüksek lisans eğitimi veren toplam 13 üniversite bulunurken, alanda aktif olarak doktora eğitimi veren sadece 6 üniversite bulunmaktadır. Karşımıza çıkan bu tablo, lisansüstü eğitim bağlamında çeviribilim disiplininin ülkemizde henüz gelişim evresinde olduğunu göstermektedir.” (Ersoy ve Balkul 2016: 152)

Ersoy ve Balkul (2016), Türkiye'deki mütercim tercümanlık veya çeviribilim bölümlerinde hazırlanan lisansüstü tezlerin "Çeviribilim Alanındaki Konu(m)ları"nı tespit ederek tablo halinde sunmuşlardır. Çeviribilim alanındaki araştırma konularının sıralandığı bu tabloda, "çeviri teknolojileri, yerelleştirme" bir arada sunulmuştur (2016: 157). Bu nedenle, "çeviri teknolojileri, yerelleştirme" konulu lisansüstü tezler, bu çalışmada birlikte ele alınmaktadır.

Yükseköğretim Kurulu (YÖK) Ulusal Tez Merkezi veri tabanında yapılan tarama neticesinde, mütercim-tercümanlık veya çeviribilim bölümlerinde hazırlanan çeviri teknolojileri, yerelleştirme konulu lisansüstü tez başlıkları tespit edilmiştir. Aşağıda sıralanan konu kapsamındaki tez başlıkları, tamamlanma yıllarına göre sıralanmış olup, hangi dilde ve üniversitede hazırlandıkları ile yüksek lisans veya doktora tezi olduğu belirtilmiştir:

1) Ayşın Özalp tarafından 1995 yılında, İstanbul Üniversitesi Çeviri Kuramı ve Uygulamaları Anabilim Dalı'nda, tamamlanan "Çeviri ortamı ve çevirmen: bir çeviri projesi örneğinde çeviri süreci içindeki kararlar açısından çevirmenin rolü” başlıklı Türkçe Yüksek Lisans Tezi.

2) Yeliz Yalın tarafından 2005 yılında, Yıldız Teknik Üniversitesi Çeviri Bilim Dalı’nda, tamamlanan "Teknik çeviri eğitimi kapsamında WEB sitelerinin yerelleştirilmesi uygulamaları için bir model önerisi” başlıklı Türkçe Yüksek Lisans Tezi.

3) Sinem Canım tarafından 2008 yılında, İstanbul Üniversitesi Çeviribilim Anabilim Dalı'nda, tamamlanan "Türkiye'de çeviri bürolarında web sitesi yerelleştirmeleri ve bu süreçte bilgi teknolojilerinin kullanımı” başlıklı Türkçe Yüksek Lisans Tezi. 
4) Özge Çetin tarafindan 2009 yılında, Muğla Üniversitesi Mütercim-Tercümanlık Anabilim Dalı'nda, tamamlanan "Çeviride insan zekâsı ve yapay zekâ" başlıklı Türkçe Yüksek Lisans Tezi.

5) Ziya Tok tarafından 2010 yılında, Kırıkkale Üniversitesi Fransızca MütercimTercümanlık Bilim Dalı'nda, tamamlanan "Fransızca bankacılık terimlerinin Türkçe'ye çevirisi: Otomatik sözlük programı" başlıklı Türkçe Yüksek Lisans Tezi.

6) Gizem Refika Bakır tarafından 2012 yılında, Sakarya Üniversitesi Çeviribilim Dalı’nda, tamamlanan "Yazılımda yerelleştirme ve çeviri” başlıklı Türkçe Yüksek Lisans Tezi.

7) Emine Öztürk tarafından 2013 yılında, Sakarya Üniversitesi Çeviribilim Dalı'nda, tamamlanan "Yerelleştirme ve çeviri: Çeviribilimde ve çeviri eğitiminde yerelleştirmenin konumu" başlıklı Türkçe Yüksek Lisans Tezi.

8) Sinem Canım Alkan tarafından 2014 yılında, İstanbul Üniversitesi Çeviribilim Anabilim Dalı'nda, tamamlanan "Web sitesi yerelleştirmelerinde bir eyleyen olarak çevirmenin konumu: Türkiye örneği" başlıklı Türkçe Doktora Tezi.

9) Halil İbrahim Balkul tarafından 2015 yılında, Sakarya Üniversitesi Çeviribilim Anabilim Dalı'nda, tamamlanan "Türkiye'de akademik çeviri eğitiminde çeviri teknolojilerinin yerinin sorgulanması: Müfredat analizi ve öğretim elemanlarının konuya ilişkin görüşleri” üzerinden bir inceleme başlıklı Türkçe Doktora Tezi.

10) Özden Şahin tarafından 2015 yılında, Hacettepe Üniversitesi Mütercim-Tercümanlık Anabilim Dalı'nda, tamamlanan "Bilgisayar çevirisi kalitesinin değerlendirmesi yöntemlerinde tutarlılık" başlıklı İngilizce Yüksek Lisans Tezi.

11) Caner Çetiner tarafından 2015 yılında, Sakarya Üniversitesi Çeviribilim Anabilim Dalı'nda, tamamlanan "Kırıkkale Üniversitesi İngilizce mütercim-tercümanlık anabilim dalı öğrencilerinin çeviri teknolojilerine yönelik tutumlarının incelenmesi" başlıklı Türkçe Yüksek Lisans tezi.

12) Mehmet Cem Odacığlu tarafından 2016 yılında, Sakarya Üniversitesi Çeviribilim Anabilim Dalı'nda, tamamlanan "Çeviribilimde yerelleştirme paradigmasına doğru" başlıklı Türkçe Doktora Tezi.

13) Ulvican Yazar tarafından 2017 yılında, Sakarya Üniversitesi Çeviribilim Anabilim Dalı'nda, tamamlanan "Yerelleştirme bağlamında kullanılan çeviri teknolojileri (Çeviribilim öğrencileri ve çeviri sektörü örneklemlerinde)" başlıklı Türkçe Doktora Tezi.

14) Selçuk Eryatmaz tarafından 2017 yılında, İstanbul Üniversitesi Çeviribilim Anabilim Dalı'nda, tamamlanan "Makine çevirisi değerlendirme dinamiklerinin çeviri piyasasının iş sınıflaması bağlamında incelenmesi için bir yöntem önerisi” başlıklı Türkçe Doktora Tezi.

15) Selahattin Karagöz tarafindan 2019 yılında, Yıldız Teknik Üniversitesi Batı Dilleri ve Edebiyatları Bölümünde (Diller ve Kültürlerarası Çeviribilim Doktora Programında), tamamlanan "Amatörler, uzmanlar, kâşifler: Türkiye'de video oyun çevirileri ve yerelleştirme süreci" başlıklı Türkçe Doktora Tezi.

16) Burcu Türkmen tarafindan 2019 yılında, Sakarya Üniversitesi Çeviribilim Anabilim Dalı'nda, tamamlanan "Dijital medyanın çeviri eğitimindeki yeri ve dijital medya edinci önerisi" başlıklı Türkçe Doktora Tezi.

(https://tez.yok.gov.tr/UlusalTezMerkezi/tezSorguSonucYeni.jsp Erişim Tarihi: 28.08.2019).

Tarama neticesinde, çeviri teknolojileri, yerelleştirme konusunda hazırlanan Türkiye'deki lisansüstü tezlerin sayısının, 2000'li yıllardan itibaren artış gösterdiği görülmektedir. Bu konuyu ele alan tez sayısındaki artışta, çeviri teknolojileri alt alanının gittikçe önem kazanmasının etkili olduğu söylenebilir. Sınır tanımayan teknolojik gelişmelerle çeviri teknolojilerinde de ciddi gelişmeler yaşanmakta ve bu alt alana verilen önemin artmasıyla bu alandaki çalışmalar da artmaktadır. 
Türkiye'deki mütercim-tercümanlık veya çeviribilim bölümlerinde hazırlanan çeviri teknolojileri, yerelleştirme konulu yukarıdaki 16 lisansüstü tezin 15'i Türkçe dilindedir. Tezlerin neredeyse tamamının Türkçe dilinde hazırlanması hem Türkçe çeviribilim literatürünün (daha özelde Türkçe çeviri teknolojileri literatürünün) gelişerek zenginleşmesine hem de çeviri teknolojileri alt alanının gelişmesine katkı sağlamaktadır. Konu kapsamındaki 16'tezden sadece biri (Özden Şahin tarafından Hacettepe Üniversitesi’nde hazırlanan yüksek lisans tezi) İngilizce dilinde hazırlanmıştır. Tezin yazım diline üniversite kuralları çerçevesinde karar verilmesi, İngilizce dilinin bu nedenden ötürü seçilmiş olduğunu düşündürmektedir. Ülkemizde hazırlanan lisansüstü tezlerin Türkçe dilinde olması, özellikle yeni doğan ve gelișmekte olan alanların veya alt alanların tanınırlığının artmasına ve bu alanlardaki yeniliklerin takip edilmesine olanak sağlamaktadır.

Konu kapsamında ülkemizde hazırlanan yukarıdaki 16 lisansüstü tezin 7'sinin Sakarya Üniversitesi'nde hazırlandığı görülmektedir. Tezlerin neredeyse yarısının Sakarya Üniversitesi'nde yürütülmesi, Sakarya Üniversitesi'nin çeviri teknolojileri alanına katkı sunmada ülkemizde öncü konumda olduğunu göstermektedir. Bu durum, ayrıca, bu alanda yetişmiş uzman akademisyenlerin üniversitede yeterli sayıda ve yetkin düzeyde olduğuna işaret etmektedir. Tezlerin 4'ünün İstanbul Üniversite'sinde, 2'sinin Yıldız Teknik Üniversitesinde, 1 tanesinin Hacettepe Üniversitesi'nde, 1 tanesinin Kırıkkale Üniversitesi'nde ve 1 tanesinin Muğla Üniversitesi'nde hazırlandığı görülmektedir. $\mathrm{Bu}$ üniversitelerde hazırlanan konu kapsamındaki lisansüstü tez sayılarının az olmasında, ilgili alanda tez çalışması yürütecek uzman akademisyen eksikliğinin kısmen etkili olduğu söylenebilir.

Ayrıca, 16 lisansüstü tezin 9'u yüksek lisans tezi, 7'si doktora tezidir. 2014 yılına kadar, Türkiye'deki mütercim-tercümanlık veya çeviribilim bölümlerinde, konu kapsamında doktora tezi yazılmadığı, sadece yüksek lisans tezi yazıldığı, 2014 yılından itibaren doktora tez sayısında hızlı bir artış yaşandığ 1 görülmektedir. Bu bulgu, çeviri teknolojileri, yerelleştirme konusunda doktora düzeyinde tez çalışması yürütecek uzman akademisyen sayısının 2014 yılından itibaren arttığına işaret etmektedir. 7 doktora tezinin 4'ünün Sakarya Üniversitesi Çeviribilim Anabilim Dalı’nda hazırlanması, yukarıda da belirtildiği üzere, üniversitenin bu alt alanda yeterli sayıda yetkin akademisyeni bünyesinde barındırmasıyla kısmen ilişkilendirilebilir. Doktora tezlerinin 2'si İstanbul Üniversitesi'nde 1 tanesi de Yıldız Teknik Üniversitesi'nde hazırlanmıştır. Çeviri alanında doktora eğitimi veren ülkemizdeki diğer üniversitelerde, çeviri teknolojileri, yerelleştirme kapsamında doktora tez çalışması yapılmadığı görülmektedir.

YÖK Ulusal Tez Merkezinde "hazırlanmakta olan tezler" üzerinden yapılan tarama sonucunda ulaşılan, çeviri teknolojileri, yerelleştirme konulu tez başlıkları aşağıdaki gibidir:

1) Caner Çetiner tarafindan hazırlanmakta olan "The Effect of Post-Editing on the Attitudes and Performance of Translation Students (Makine Çevirisi Sonrası Düzeltme Iş̧leminin Çeviri Öğrencilerinin Tutum ve Çeviri Performanslarına Etkisi)" başlıklı İngilizce Doktora Tezi, Ankara Hacı Bayram Veli Üniversitesi.

2) Azime Deniz Bacaksız tarafindan hazırlanmakta olan "The Future of Translation Studies through Artificial Intelligence (Yapay Zekâ ile Çeviri Çalışmalarının Geleceği)" başlıklı İngilizce Yüksek Lisans Tezi, Atılım Üniversitesi.

3) Özden Şahin tarafindan hazırlanmakta olan "Çeviri Belleklerindeki Farklı Derecelerdeki Bulanık Eşleşmelerin Çevirmenin Çabasına Etkisi (The Effect of Different Fuzzy Match Rates in the Translation Memories on the Effort of Translators)" başlıkl Türkçe Doktora Tezi, Sakarya Üniversitesi. (https://tez.yok.gov.tr 28.08.2019)

Hazırlanmakta olan yukarıdaki tez başlıkları incelendiğinde, 3 tezden 2'sinin doktora tezi, 1 'inin yüksek lisans tezi olduğu görülmektedir. Sakarya Üniversitesi'nin yanında, Ankara Hacı Bayram Veli Üniversitesi’nin de çeviri teknolojileri kapsamında doktora tezi yürüttüğü 
görülmektedir. Bir vakıf üniversitesinde (Atılım Üniversitesi) de konu kapsamında yüksek lisans tezi yürütüldügü görülmektedir. Çeviri teknolojileri alt alanında lisansüstü tez hazırlayan üniversiteler arasına Ankara Hacı Bayram Veli Üniversitesi ve Atılım Üniversitesi’nin eklenmesi, olumlu bir gelişme olarak değerlendirilmektedir. Bununla birlikte, hazırlanmakta olan tezlerin 2 tanesi İngilizce dilinde, 1 tanesi Türkçe dilindedir. Uluslararası literatüre paralel bir şekilde ilerleyebilmek için, ilgili alanda kendi öz dilimizde yazılmış kaynakların yeterli sayıda ve düzeyde olması bir gerekliliktir.

\section{2. Çeviri Teknolojileri, Yerelleştirme Konulu Lisansüstü Tezlerin Türkçe Çeviribilim Literatürü Bağlamında İncelenmesi}

Çalışmanın bu bölümünde, Türkiye'deki mütercim-tercümanlık veya çeviribilim bölümlerinde hazırlanan çeviri teknolojileri, yerelleştirme konulu lisansüstü tezler Türkçe çeviribilim literatürü bağlamında ayrıntılı bir şekilde incelenecektir. Bu doğrultuda, konu kapsamındaki lisansüstü tezler aracılığıyla, Türkçe çeviribilim literatürüne nasıl katkı sağlandığ1 değerlendirilecektir.

Özalp tarafından hazırlanan "Çeviri ortamı ve çevirmen: Bir çeviri projesi örneğinde çeviri süreci içindeki kararlar açısından çevirmenin rolü” (1995) başlıklı yüksek lisans tezi, hazırlanma yılı itibarıyla, çeviri teknolojilerini çeviribilim bağlamında ele alan ilk Türkçe lisansüstü tez olması bakımından önemlidir. Bu çalışma, "Çeviri projesinin tanıtımı" (1995: 8), çeviri projesinin yazılım üzerinden uygulanması ve "Bilgisayar destekli çevirinin aşamaları" (1995: 29) ile ilgili ayrıntılı bilgiler sunması bakımından, özellikle çeviri teknolojilerinin kavramsal ve uygulama alanına katkı sunmaktadır. Çeviri teknolojileri alt alanının yurt dışında daha hızlı geliştiği göz önünde bulundurulduğunda, bu tezin, alana ait yabancı kökenli kavramların Türkçe karşılık ve kullanımlarını sunması bakımından ayrıca önem arz ettiği söylenebilir. Bu bağlamda, bu çalışma, bir çeviri projesi örneği üzerinden çeviri teknolojileri alanına ait temel kavram ve bilgileri sunarak alanın Türkiye'deki tanınırlığına ve Türkçe çeviribilim literatürünün gelişmesine katkı sağlamaktadır.

Yalın tarafından hazırlanan "Teknik çeviri eğitimi kapsamında WEB sitelerinin yerelleştirilmesi uygulamaları için bir model önerisi” (2005) başlıklı yüksek lisans tezinde, "web sitelerinin yerelleştirilmesi konusunda eğitim veren çeviri bölümlerinde uygulanabilecek sekiz aşamalı bir model önerisi” sunulmuştur. Önerilen eğitim modelinin uygulama aşamalarını ayrıntılı bir şekilde ele alan bu çalışma, özellikle çeviri eğitimine katkı sunmaktadır. Ayrıca, çeviri alanında hızla gelişmekte olan yerelleştirmenin, çeviri eğitimi veren bölümlerin müfredatlarında yer alması gerektiği vurgulanmaktadır. Hazırlandığı yıl itibarıyla, yerelleştirme konusunu çeviri bağlamında ele alan ilk Türkçe lisansüstü tez olan bu çalışmanın, Türkçe çeviribilim literatüründe, yerelleştirme ve çeviri eğitimi konusundaki kaynak boşluğunun doldurulmasına katkı sağladığı söylenebilir.

Canım tarafından hazırlanan "Türkiye'de çeviri bürolarında web sitesi yerelleştirmeleri ve bu süreçte bilgi teknolojilerinin kullanımı" (2008) başlıklı yüksek lisans tezi, "çeviribilim literatüründe yerelleştirme sürecinin, bu süreçte bilgi teknolojilerinin kullanımının, sürecin aktörlerinin ve aktörlerin görev kapsamlarının nasıl betimlendiğini göstermekte" ve "Türkiye'de web sitesi yerelleştirme sürecinin çeviribilim literatüründe tanımlanan biçimiyle işleyip işlemediğini, çeviri bürolarıyla yapılan bir anket çalışmasının verileri ışığında tartışmaktır" (2008: iii). Canım'ın çalışması, Türkiye'de çeviriye bağlı yerelleştirme sektörünün nasıl geliştiği ve web sitesi yerelleştirme sektörünün gelişmesiyle çeviri sektöründe ve eğitiminde yaşanan gelişmeleri açığa çıkarması bakımından önemlidir. Çalışmada uygulanan anketin çeviri eğitimine sunduğu katk1, yerelleştirme projelerinde görev alan çevirmen profillerinin aldıkları eğitim bağlamında değerlendirilmesidir. Anketin ilgili bölümünde, "Çeviri Bölümü Mezunlarının Elektronik Araç Bilgi ve Becerisi" sorgulandığında çeviri işletmelerinin çoğunluğunun yanıtı "kesinlikle yetersiz" veya "yetersiz" şeklindedir (150). Anket sorularından "Web Sitesi Yerelleştirme Projelerinde Görev Alan Çevirmenlerin Niteliklerinin Önem Sıralaması”yla ilgili soruya çeviri bürolarının 
çoğunluğu önceliği elektronik araç kullanma bilgisi ve becerisine vermişlerdir (153). Web sitesi yerelleştirme sürecini betimleyen ilk Türkçe lisansüstü tez olan bu çalışma, alandaki akademik çalışma boşluğunu doldurmaktadır (187). Yerelleştirmenin Türkiye'deki çeviri piyasası ve eğitimindeki yerine ilişkin bir değerlendirmenin yapıldığı bu çalışma, hem çeviri eğitimindeki boşluğun hem de çeviribilim literatüründe yerelleştirme konusundaki Türkçe kaynak eksikliğinin giderilmesine katkı sağlamaktadır. $\mathrm{Bu}$ çalışma, yerelleştirmenin çeviri piyasası ve çeviri eğitimindeki yerini Türkiye örneklemi üzerinden ele alan ilk lisansüstü çalışma olması bakımından, Türkçe çeviribilim literatüründe konu kapsamındaki temel başvuru kaynaklardan biri olarak görülebilir.

Çetin tarafından hazırlanan "Çeviride insan zekâsı ve yapay zekâ" (2009) başlıklı yüksek lisans tezinde, insan zekâsıyla (insan çevirmen tarafindan) yapılan çevirilerle yapay zekâ ile tasarlanan SameTran çeviri programı tarafından yapılan çeviriler karşılaştırılarak ikisi arasındaki benzerlik ve farkl111klar ortaya koyulmuştur. Çetin, "Yapay Zekâ'nın insan yerine seçtiği cümleler ve kelimeler, şimdilik, İnsan Zekâsı ile karşılaştırıldığında yeterli değildir" şeklinde bir sonuca ulaşmış ve bunu, "yapay zekâ ile ilgili çalışmalarda, çeviri eylemini ve sürecini yorumlamaya ve çözümlemeye çalışan Çeviribilim'den yararlanılmamasına" bağlamıştır (2009: 2). Ürün odaklı olan bu çalışmada, insan zekâsı ile yapay zekâ tarafindan çeşitli metin türlerinde (roman, reklam metni, resmi belge ve makale) yapılan çeviriler karşılaştırılarak Toury'nin kaynak dizge normlarına göre yeterlilik, erek dizge normlarına göre kabul edilebilirlik açısından değerlendirilmiştir. Ayrıca, her iki çeviriyi güvenilirlik, ideoloji ve zaman açılarından da değerlendirmiştir. Yapay zekâ ile tasarlanmış SameTran'ın en üst versiyonu SameTech üzerinden yapılan çevirilerin yeterli ve kabul edilir çeviriler olmadığını, hatta insan yardımıyla kaynak metinde sözdizimi ve imla kurallarına ilişkin bazı düzenlemelerden sonra bile yeterli sonuç alınamadığı ortaya çıkmıştır. Çetin, yapay zekâ ile tasarlanmış bu program üzerinden yeterli sonuç alınamamasını programın veri tabanındaki ve dilbilgisi veritabanındaki eksikliklere bağlamış ve "Yapay Çeviri Normları ve Yapay Çeviri Algoritması adımları" önerisinde bulunmuştur. (Çetin 2009) Çalışma, yapay zekâ ile çeviribilimi bir araya getirmesi bakımından çevirinin disiplinlerarası yönüne dikkat çekmektedir. Çalışma, Çetin'in aktarımıyla, "Çeviri ve Yapay Zekâ çalışmalarına giriş niteliğinde" (2009: 108) olması ve önerdiği Yapay Çeviri Algoritmasının, alanda "temel oluşturabileceği düşünülen bir algoritma adımları önerisi" (108) olması nedeniyle alana katkı sağlamaktadır. Çeviride insan zekâsı ve yapay zekâ ilişkisini çeviribilim bağlamında ele alan bu çalışma, hem konusu hem de yenilikçi yaklaşımı nedeniyle çeviribilim literatüründe bu konudaki Türkçe kaynak boşluğunun doldurulmasına katkı sağlamaktadır.

Tok tarafindan hazırlanan "Fransızca bankacılık terimlerinin Türkçe'ye çevirisi: Otomatik sözlük programı" (2010) başlıklı yüksek lisans tezinin çeviri teknolojileriyle ilişkisi, çalışma kapsamında bir bilgisayar destekli Fransızca-Türkçe Bankacılık Terimleri Sözlüğü hazırlanmasıdır (2010: 3). Çalışma, diğer teknik alanlarda bilgisayar destekli terimler sözlüklerinin hazırlanmasına zemin oluşturması bakımından önem arz etmektedir. Çalışmada, basılı sözlük ve kaynakların taranmasıyla elde edilen bankacilık terimleri, "MySQL veri tabanıyla birlikte, Delphi 7 programı üzerinde hazırlanmıştır” (2010: 59). Bu kapsamda yapılan çalışmalar, teknik alanlardaki terim kaynaklı sorunların ve eksikliklerin giderilmesinde önemli bir rol oynamaktadır. Bilindiği gibi, elektronik terim veri tabanları, artık çeviri belleği sistemleri üzerinden çeviri yapan çevirmenler için en önemli kaynakların başında yer almaktadır. Çalışma kapsamında oluşturulan bilgisayar destekli sözlük programının, diğer araştırmalara ve diğer uzmanlık alanlarıyla ilgili terim çalışmalarına temel oluşturduğu söylenebilir. Bu çalışmanın, çeviri teknolojileri kapsamında terim veri tabanı oluşturma, terminoloji araçları ve yönetimi konusundaki Türkçe kaynak ihtiyacının giderilmesine katk1 sağladığı söylenebilir.

Bakır tarafından hazırlanan "Yazılımda yerelleştirme ve çeviri" (2012) başlıklı yüksek lisans tezinde, çeviribilimle etkileşim içerisinde olan yerelleştirme konusu detaylı bir şekilde 
incelenmektedir. Bakır'ın, çalışmasının önsözünde belirttiği üzere, “Türkiye'de yeni şekillenmeye başlayan yerelleştirme konusu”na yönelmesi Türkiye'de "yapılan çalışmalara katkıda bulunmak ve çeviri gerçeklerine yönelik bazı yeni koşullara dikkat çekmektir" (2012). Çalışmada, yerelleştirme projelerinde yaygin kullanılan hafiza programları (Catalyst, Passolo, Rc-Wintrans, Trados, Multilizer, Visual Localize) detaylandırarak ele alınmış (2012: 32-39) ve yerelleştirmede kullanılan programlar tablo halinde karşılaştırmalı olarak sunulmuştur (2012: 42-46). Yerelleştirmenin çeviri ile ilişkilendirilmesinin çok yeni olduğuna vurgu yapan Bakır, "Yerelleştirmenin yöntemlerini ve süreçlerini araştırmadan önce" (2012: 7) küreselleşme ve uluslararasılaştırmanın yerelleştirmeye etkisini irdelemiştir. Yerelleştirme yazılımları üzerinden örnek çalışmalar sunarak, bu yazılımların uygulamada nasıl kullanıldığını göstermiştir. Çalışmada sonuç bölümü bulunmaması, çalışmada ele alınan konuyla ilgili genel bir değerlendirme yapılmasına engel olmuştur. Çalışmanın konusu ve amac1 göz önünde bulundurulduğunda, çeviribilim literatüründe, yerelleştirme ve çeviri teknolojileri eğitimi konularındaki Türkçe kaynak ihtiyacının giderilmesine katkı sağladığ1 söylenebilir.

Öztürk tarafindan hazırlanan "Yerelleştirme ve çeviri: Çeviribilimde ve çeviri eğitiminde yerelleştirmenin konumu" (2013) başlıklı yüksek lisans tezinde, çeviri bağlamında yerelleştirme sektörüne ve yerelleştirme süreçlerine değinilmekte ve çeviri sektöründe çeviri teknolojilerinin yaygınlaşmasıyla değişen çevirmen profiline bağlı olarak çeviri eğitimindeki değişim ve dönüşümler irdelenmektedir (2013: IV). "Çeviri eğitimi ve yerelleştirme" (51) başlıklı bölümde, "yerelleştirmenin çeviri eğitimine etkileri” (51) ve "Türkiye'de Çeviri Eğitimi Veren Bölümlerde Çeviri Teknolojileri Eğitimi” (59) ele alınmaktadır. Ayrıca, yurt dışındaki mevcut durum ortaya konularak yapılan karşılaştırma, Türkiye'deki eksik veya boşlukların tespit edilmesine olanak sağlamaktadır. Bu bağlamda, Türkiye'deki çeviri eğitiminde, sektörel ve teknolojik gelişmelere cevap veren köklü değişiklikler olmadığı ortaya çıkmıştır (2013: 1). Öztürk, yurt dışındaki çeviri eğitimi veren üniversitelerde çeviri teknolojileri lisansüstü programlarının yer aldığına ayrıca dikkat çekmiştir (2013: 57-58). Çalışmada, AB desteğiyle yürütülen "LETRAC (Çeviri Eğitimi Müfredatı için Dil Mühendisliği)" projesi kapsamında geliştirilen eğitim modeli tanıtılmış, hedefleri sayılmış, modeldeki modüller ("Modül A: Bilgisayar Bilimine Giriş, Modül B: Çevirmenler için Masaüstü Yayıncılık / Bilgi Teknolojileri, Modül C: Dil Mühendisliği”) açıklanmıştır (2013: 63-66). Öztürk, Türkiye'deki çeviri eğitimini, LETRAC eğitim modeli üzerinden değerlendirdiğinde, uyum sürecinin geriden geldiği ve bu alandaki boşlukların hala doldurulamadığı sonucuna ulaşmıştır: "Aynı zamanda, üniversitelerin çeviri eğitimi programlarının da profesyonel çeviri sektörünün gerekliliklerini karşılayacak bir müfredata sahip olmadığ1 görülmüştür. LETRAC eğitim modeli ele alınarak incelendiğinde bölümlerimizde verilen eğitimin yetersiz kaldığı, ders içeriklerinden de görüldüğü üzere kuramsal ve uygulama acısından yetersiz kalındığ1 belirlenmiştir" (2013: 69-70). Yerelleştirmeyi, çeviribilim ve çeviri eğitimi bağlamında ele alan bu çalışma, Türkçe çeviribilim literatüründe, çeviri ve yerelleştirme konulu kaynak eksikliğinin giderilmesine katkı sağlamaktadır.

Canım Alkan tarafından hazırlanan "Web sitesi yerelleştirmelerinde bir eyleyen olarak çevirmenin konumu: Türkiye örneği" (2014) başlıklı doktora tezinin amacı, "sosyal bilimler literatüründe ve daha çok Türkiye özeline inerek çeviri ve yerelleştirme endüstrisinde kavramın nasıl algılandığını, içeriğinin nasıl doldurulduğunu sorgulamak ve çeviri ile ilişkisinin nasıl tasarlandığını araştırıp durumu betimlemektir" (2014: IV). Canım Alkan'ın, İşlevsel Çeviri Kuramlarının 1şı̆̆ında, yerelleştirme kavramını inceleyip açılaması (64), yerelleştirme endüstrisinin çevibilimden faydalanmasına olanak sağlamaktadır. Doküman analizi yanında, çevirmenlerle görüşme yapılan bu kapsamlı çalışmanın çeviribilim literatüründeki önemini yazar şu sözlerle ifade etmiştir: "Yerelleştirme konusu çeviri dünyasının gündeminde bu kadar önemli bir yer kaplamasına karşın Türkçe çeviribilim literatüründe pek fazla ele alınan bir konu olmamıştır. Web sitesi yerelleştirmelerinde bir eyleyen olarak çevirmenin konumu konulu bu doktora tezinin, yerelleştirme alanında yapılacak yeni çalışmaların önünü açacă̆ 
Yerelleştirmede çevirmenin konumunu Türkiye örneği üzerinden ilk kez ele alan bu çalışmanın, Türkçe çeviribilim literatüründe, bu konudaki boşluğu doldurduğu söylenebilir.

Balkul tarafından hazırlanan "Türkiye'de akademik çeviri eğitiminde çeviri teknolojilerinin yerinin sorgulanması: Müfredat analizi ve öğretim elemanlarının konuya ilişkin görüşleri üzerinden bir inceleme" (2015) başlıklı doktora tezinde, "Türkiye örnekleminde çeviri teknolojilerinin çeviri eğitimindeki konumunu sorgulamaktadır" (2015: IX). Çalışma kapsamında, Türkiye'de çeviri eğitimi veren bölüm müfredatları incelendiğinde, çeviri teknolojileri ile ilgili derslerin genellikle seçmeli statüde olması, bu derslere gereken ağırlığın verilmemesi (sayı ve süresinin az olması) ve diğer çeviri derslerinde çeviri teknolojilerinin kullanılmamasından dolayı, çeviri teknolojilerinin çeviri eğitimine etkin bir şekilde entegre edilmediği sonucu ortaya çıkmış ve "Gabr'ın (2000) müfredat geliştirme modeli temel alınarak pedagojik tavsiyelerde bulunulmuştur" (2015: IX). Balkul, "Çeviri Eğitimine Teknoloji Odaklı Yaklaşımları" açıkladıktan sonra "Çeviri Teknolojilerinin Çeviri Eğitimine Entegre Edilmesini Konu Edinen Projeleri” ele almaktadır (2015: 58-66). Çalışmanın, çeviri teknolojilerinin kullanımı ve BDÇ eğitimi konusunda akademisyen görüşlerini ele alması bakımından, ülkemiz çeviribilim literatüründe bir ilk olduğu (Balkul 2015: 7) ve çeviribilim literatürümüzde bu konudaki boşluğu doldurduğu söylenebilir.

Şahin tarafindan hazırlanan "Bilgisayar çevirisi kalitesinin değerlendirmesi yöntemlerinde tutarlılık" (2015) başlıklı yüksek lisans tezi, "İngilizce ve Türkçe arasında çeviri yapan Google Translate, Proçeviri ve Sametran bilgisayar çevirisi programlarının kalitelerini değerlendirerek literatürdeki bu boşluğu doldurmayı hedeflemektedir" (2015: V). Çalıșmada, İngilizce'den Türkçe'ye bilgisayar çevirisinin kalitesinin değerlendirmesindeki tutarlık araştırılmıştır. İnsanların bilgisayar çevirisinin kalitesini nasıl algıladıkları, dört farklı metin türünden örneklerin üç farklı bilgisayar çevirisi programı üzerinden incelenmesiyle ortaya konmuştur. 20 tercümanlık öğrencisinin katılımıyla, bilgisayar programı çıktıları anlaşılabilirlik, sadakat ve genel kaliteye göre değerlendirilmiştir. Hata incelemesi neticesinde, bilgisayar çevirisi program çıktılarındaki hata sayılarında ve ayrıca katılımcıların değerlendirmeleri arasında benzerlikler olması, bilgisayar çevirisini tutarlı bir şekilde değerlendirmenin mümkün olduğunu ortaya koymuştur (2015: V). Konusu ve orijinalliği bakımından Türkiye'de ilk olan bu tez, Türkçe dilinde yazılmış olsaydı Türkçe çeviribilim literatürünün gelişmesine daha fazla katkı sunabilirdi.

Çetiner tarafından hazırlanan "Kırıkkale Üniversitesi İngilizce mütercim-tercümanlık anabilim dalı öğrencilerinin çeviri teknolojilerine yönelik tutumlarının incelenmesi” (2015) başlıklı yüksek lisans tezinin amacı, "çeviri bölümü öğrencilerinin çeviri teknolojilerine yönelik tutumlarının, ders öncesi (ön-test) ve ders sonrası (son-test) değerlendirme yöntemiyle incelenmesidir" (2015: V). Çetiner, çalışmasında, çevirmen eğitiminde çeviri teknolojileri ile ilgili derslerin az olduğuna ve bu derslerin ihmal edildiğine vurgu yapmaktadır: "Buna karşın geleceğin çevirmenlerinin eğitimlerinde çeviri teknolojileri konusu ya çok az bir yer tutmakta ya da hiç yer almamaktadır. Bu dersler çoğunlukla ihmal edilmektedir" (2015: 2). Çetiner, makine çevirisi yaklaşımlarına değinerek (14-15) çeviri belleği sistemlerinin işleyişini kavramsal çerçevesiyle birlikte ayrıntılı bir şekilde sadeleştirilerek aktarmıştır. Sonrasında, bu sitemlerde önemli bir işlevi olan eşleşme türleri ve metin hizalama adımları, çeviri belleği sistemi (Memsource cloud) üzerinden örneklerle açıklanmıştır (19-30). Çalışmada uygulanan anket, öğrencilerin BDÇ dersini almadan önce ve aldıktan sonra çeviri teknolojilerine yönelik tutumlarında, "Çeviri Teknolojileri ve Çeviride Kalite İlişkisi konusundaki tutumlarında", "Çeviri Teknolojileri ve Çeviride Verimlilik İlişkisi konusundaki tutumlarında" ve "Çeviri Teknolojilerinin ders müfredatlarında yer almasına ilișkin tutumlarında" olumlu yönde anlamlı bir değişiklik olduğunu ortaya koymuştur (71-72). Bu bağlamda, BDÇ derslerinin müfredatlarda mutlaka yer alarak, öğrencilere BDÇ araçlarının kullanımına yönelik gerekli bilgi ve becerilerin kazandırılması gerektiğine vurgu yapmıştır. Çeviri teknolojileri ve çeviri eğitimi konusunu detaylı bir şekilde ele alan bu çalışma, Türkçe çeviribilim literatüründe, konu kapsamındaki kaynakların zenginleştirilmesine katkı sağlamaktadır. 
Odacıoğlu tarafından hazırlanan "Çeviribilimde yerelleştirme paradigmasına doğru” (2016) başlıklı doktora tezinde, "yerelleştirmenin çeviribilim açısından bir paradigma adayı olup olmadığını tartışmaya açılmıştıı" (2016: Viiï). "Yerelleştirme endüstrisi çeviribilim çatısı altında irdelenecek yeni paradigmalardan birinin oluşmasına katkı yapabilir mi?" (2016: 4) sorusu tezde ortaya atılan tartı̧̧mayı sonuçlandırmak için yanıtlanmaya çalışılımıştır. Ortaya çıkan sonuçlar, yazarın bu tezi yazmasında çıkış noktalarından biri olan "yerelleştirme alanının da, çeviribilimin farklı paradigması olarak bir yenilik sunduğu düşüncesini doğrulamıştır" (2016: 179). Paradigmanın oluşumu için bazı sorunların yaşanması ve bu sorunların çözülerek paradigmanın iyileştirilmesi gerektiğine Pym'e atıfta bulunarak vurgu yapan Odacioğlu, yerelleştirmenin 9 problemini ele alarak incelemiştir (2016: 180). Yaşanan problemler ve çözümleri aktarılmıştır: En temel sorunlar arasında, "yerelleştirmede çevirinin bir adıma indirgenmesi, akademi ve endüstri arasındaki boşluk ve kopukluk" (180) sayılmıştır. Yerelleştirme alanıyla, çeviribilimin diğer disiplinlerle ilişkisinin sınırının yeniden çizildiği ve mevcut sınırların aşılmasıyla, çeviribilimi disiplinlerötesi bir bilim dalı haline getirdiği; çeviri eğitimi müfredatlarına yerelleştirme ile ilgili derslerin girdiği; uluslararasılaştırma kavramıyla kaynak metin ve erek metin arasındaki ilişkiye yeni bir boyut getirildiği (yerelleştirmeye uluslarasılaştırılmış aracı bir metin üzerinden başlanır); eşdeğerlik kavramı yeniden temellendirilerek yapay eşdeğerlik kavramının ortaya atıldığı; yerelleştirmenin çeviribilimin mevcut terminolojisine yeni anlamlar yüklediği (yeniden yazım ve sözde çeviri kavramlarının yerelleştirme alanında farklı anlamlar kazanması); çevirmen rolüne, proje yöneticiliği, dil mühendisliği, yerelleştirme mühendisliği, post-editörlük, pazarlama danışmanlığ $1 \mathrm{vb}$. sorumluluk ve rollerin eklenmesiyle sınırların genişletildiği; çeviribilim kuramlarının yeni gelişmeler çerçevesinde yorumlanarak kuramların yerelleştirme çatısı altında yeniden temellendirildiği üzerinde durulmuştur. Çalışmada, yerelleştirme, çeviribilim alanında sosyal bir paradigma olarak değerlendirilmiştir çünkü yerelleştirme çeviri alanında köklü değişimler meydana getirmiştir (2016: 178-187). Yerelleştirme konusunu çeviribilimin kuramsal bağlamında ele alan bu çalışma, Türkçe çeviribilim literatüründe bu konudaki boşluğun doldurulmasında öncü bir rol oynamaktadır.

Yazar tarafından hazırlanan "Yerelleştirme bağlamında kullanılan çeviri teknolojileri (Çeviribilim öğrencileri ve çeviri sektörü örneklemlerinde)" (2017) başlıkl doktora tezinde, yerelleştirme uygulamalarının Türkiye'deki konumu, çeviri sektörü ve çeviri eğitimi üzerinden sorgulanmıştır. $\mathrm{Bu}$ doğrultuda, çeviri sektöründe yer alan firma yöneticilerine ve çeviribilim/mütercim-tercümanlık bölümlerindeki öğrencilere anket uygulanmıştır. Nicel ve nitel araştırma yöntemlerine başvurulan bu çalışmada, çeviri eğitimi müfredatındaki yerelleştirme derslerinin konumu, Türkiye'de çeviri eğitimi veren üniversitelerin müfredatlarının analiziyle belirlenmiştir. Çalışma neticesinde, çeviri bölümlerinde okuyan öğrencilerin yerelleştirme alanıyla ilgili bilgilerinin yetersiz olduğu sonucuna ulaşılmış, bu doğrultuda, üniversite ve sektör işbirliğine gidilmesi gerektiğinin altı çizilmiştir (Yazar, 2017). Çalışma, çeviri sektörü ve çeviri eğitiminde yerelleştirmenin konumunu ele alması bakımından, Türkçe çeviribilim literatüründe, yerelleştirme konusundaki kaynakların geliştirilip çeşitlendirilmesine katkı sağlamaktadır.

Eryatmaz tarafından hazırlanan "Makine çevirisi değerlendirme dinamiklerinin çeviri piyasasının iş sınıflaması bağlamında incelenmesi için bir yöntem önerisi" (2017) başlıklı doktora tezi, "çeviri piyasasının insan-makine etkileşimi temeline dayanarak bir değerlendirme yöntemi sunmaktır. Bu amaçla, günümüzde yaygın kullanılan nöral makine çeviri sistemi olarak Google Translate ve kalite değerlendirme yöntemi olarak House modeli ele alınıp çeviri dünyasını ve çeviri teknolojilerini araştıran kurumların raporlarına dayanarak piyasa odaklı bir çeviri sınıflandırması oluşturulmuştur" (Eryatmaz 2017). Oluşturulan sinıflandırma çerçevesinde, makine çevirisi çıktılarını değerlendirmede kullanılabilecek bir yöntem önerisi geliştirilmiştir. Çalışmanın, Türkçe çeviribilim literatüründe, çeviri teknolojileri kapsamında makine çevirisi konusundaki kaynakların geliştirilmesine katkı sağladığı söylenebilir. 
Karagöz tarafından hazırlanan "Amatörler, uzmanlar, kâşifler: Türkiye'de video oyun çevirileri ve yerelleştirme süreci" (2019) başlıklı doktora tezi, "Türkiye'de gönüllü ve profesyonel video oyun yerelleştirme pratiklerini bütüncül bir bakış açısıyla betimlemeyi amaçlamaktadır" (Karagöz, 2019). Çalışma, Türkçe çeviribilim literatürüne, video oyun yerelleştirme konusunda kaynak sunarak, bu konudaki boşluğun doldurulmasına katkı sağlamaktadır.

Türkmen tarafından hazırlanan "Dijital medyanın çeviri eğitimindeki yeri ve dijital medya edinci önerisi" (2019) başlıklı doktora tezi, "yükseköğretimde çeviri eğitimi alanında dijital medya araç, gereç ve kaynaklarının çeviri edinçleri bağlamında tanıtılması ve kullanılmasını amaçlamaktadır" (2019: İX). Çalışmada, çeviri eğitiminde kullanılmak üzere dijital medya edinci önerisi sunulmakla birlikte, öğrencilere uygulanan anket aracılı̆̆ıyla öğrencilerin dijital medya araçları ve çeviri teknolojileri kullanımı hakkındaki davranış ve tutumları ölçülmüştür. Anket sonuçları göz önünde bulundurularak, çeviri eğitiminde dijital medya edincinin sağlanması için “Çeviride Dijital Medya I-II" dersleri önerilmiştir (2019:IX). Bu dersler için içerik önerisinde de bulunan Türkmen, çeviri teknolojileri araçlarını da ders içeriklerine dâhil ederek yerelleştirme, görsel-işitsel çeviri programları, çeviri bellekleri, makine çevirisi, dijital sözlükler, bütünceler vb. araçları da ders kapsamına almıştır (2019: 179-181). Çalışma, dijital medya edincini çeviri teknolojileri eğitimi bağlamında ele alması bakımından, Türkçe çeviribilim literatüründe konu kapsamındaki kaynakların çeşitlendirilerek zenginleştirilmesine katkı sağlamaktadır.

Hazırlanma aşamasında olan tez başlıkları incelendiğinde, Çetiner tarafından İngilizce dilinde hazırlanmakta olan doktora tezinin, makine çevirisi sonrası düzeltme işlemini (post-editing) ele aldığı, Bacaksız tarafından İngilizce dilinde hazırlanmakta olan yüksek lisans tezinin, yapay zekâyı çeviri çalışmaları bağlamında ele aldığı, Şahin tarafından Türkçe dilinde hazırlanmakta olan doktora tezinin, çeviri yazılımlarında bulanık eşleşmelerin çevirmenin çabasına etkisini irdelediği görülmektedir. Çeviri teknolojileri alanında Türkiye'de hazırlanmakta olan lisansüstü tezlerin, daha önce ele alınmamış veya çok az ele alınmış konulara yönelmesi, alandaki ihtiyaç ve eksikliklerin giderilmesi yönünde bir çabaya işaret etmektedir. Çeviri teknolojileri alt alanındaki gelişmelere paralel olarak güncel konulara yönelen bu tezlerin, Türkçe çeviribilim literatüründeki kaynak boşluklarının doldurulmasına katkı sağlayacağı söylenebilir.

\section{Değerlendirme}

Konu kapsamındaki lisansüstü tezler detaylı bir şekilde incelendiğinde, çeviri teknolojileri, yerelleştirme konusunun çeviribilimin kuramsal ve uygulama alanları açısından ele alındığı görülmüştür. Çeviribilimin uygulama alanında en fazla ele alınan konu, çeviri teknolojilerinin çeviri eğitimindeki yerinin sorgulanması olmuştur. Çeviribilimin kuramsal alanında ise çeviri teknolojileri ve yerelleştirmenin çeviribilimde nasıl bir paradigma değişikliğine yol açtığı ele alınmıştır. $\mathrm{Bu}$ çerçevede, bazı çeviribilim kuramları yeni bakış açılarıyla yeniden değerlendirilmiş̧ir. Ayrıca, görgül ve ampirik yönteme dayalı konu kapsamındaki tez çalışmalarından elde edilen bulgular, çeviribilimin uygulama alanında kullanılabilecek (eğitim) model önerileri geliştirilmesine olanak sağlamıştır. Genel olarak, konu kapsamındaki lisansüstü tezler, teknolojik gelişmelerle birlikte çeviribilimin kuramsal ve uygulama alanlarında meydana gelen değişim ve dönüşümlerin açığa çıkarılmasında etkin bir rol oynamışlardır.

Balkul, çeviri teknolojileri konulu çalışmaları, genel olarak, üç başlık altında toplamıştır: "•Makine çevirisi hakkında yapılan kuramsal ve deneysel çalışmalar, •BDÇ araçlarının üretimi, değerlendirilmesi ve tanıtımını konu alan kuramsal ve deneysel çalışmalar, •Çeviri teknolojilerinin öğretilmesi ve akademik çeviri eğitiminde yer almasını konu alan deneysel ve kuramsal çalışmalar" (2015: 41). Çalışma kapsamında incelenen 16 lisansüstü tez çalışması, bu üç genel konu başlığ1 çerçevesinde değerlendirildiğinde, Türkiye'deki çeviri bölümlerinde yürütülen çeviri teknolojileriyle ilgili tezlerin, genel olarak, bu üç genel başlığı kapsadığı görülmektedir. Tezlerden 3 tanesi, makine çevirisini (Çetin'in Yüksek Lisans Tezi; Şahin'in Yüksek Lisans Tezi; 
Eryatmaz'ın Doktora Tezi); 3 tanesi, çeviri teknolojilerinin öğretilmesini ve akademik çeviri eğitimindeki yerini konu alan (Özalp'ın Yüksek Lisans Tezi; Balkul'ın Doktora Tezi; Çetiner'in Yüksek Lisans Tezi) çalışmalardır. Bu çalışmaların bazılarının, BDÇ araçlarının tanıtımını ve değerlendirilmesini de kapsadığı görülmüştür.

Çalışma kapsamında incelenen 16 lisansüstü tezin 8 tanesinin yerelleştirme konusunu ele aldığı tespit edilmiştir. Yerelleştirme konusunun çeviribilimin uygulama ve kuramsal açılarından ele alındığ 1 bu tez çalışmaları, Türkçe çeviribilim literatüründeki kaynak boşluğunun doldurulmasına katkı sağlamaktadır. Canım, yerelleştirme konusundaki kaynak eksikliğini ve akademik çalışma boşluğunu şu sözlerle ortaya koymuştur: "Bu çalışma, Türkiye'deki çeviri bürolarındaki web sitesi yerelleştirme sürecini betimleyerek alandaki sınırlı çalışmalara katkıda bulunmayı amaçlamakta ve aynı zamanda bu alandaki akademik çalışma boşluğu konusunda farkındalık yaratarak yerelleştirmenin diğer türlerinde de yapılacak araştırmalara duyulan ihtiyacı vurgulamaktadır" (2008: 187). 2012 y1lından itibaren yerelleştirme konulu lisansüstü tezlerin sayısında ciddi bir artış olması, bu alandaki çalışma boşluğu konusundaki farkındalığın oluşmaya başladığına işaret etmektedir. Öyle ki yerelleştirme konulu 8 tezin 6's1 2012 y1lından itibaren yazılmıştır.

İnceleme neticesinde, tezlerin, genel olarak, Türkiye'de eksikliği hissedilen hiç ele alınmamış konulara veya çok az ele alınmış konulara yöneldiği görülmüştür. Bununla birlikte, çeviri teknolojileri ve yerelleştirmenin çeviribilimi kuramsal açıdan ele aldığı tez sayısı oldukça azdır. Bu tür çalışmaların artırılması, çeviribilimin gelişmesine olanak sağlayacaktır. Örneğin; Odacioğlu (2016), yerelleştirmenin sosyal bir paradigma olduğu tezini savunduğu doktora tezinde, çeviribilim kuramlarının yerelleştirme bağlamında tekrar değerlendirilmesiyle çeviribilime yeni bir boyut kazandırıldığına vurgu yapmıştır. Ayrıca, yapay zekâ ve çeviri ilişkisini ele alan çalışmaların artırılması çeviribilimin kuramsal ve uygulama alanının gelişmesine katkı sağlayacaktır.

Çeviri teknolojileri-terminoloji ilişkisini ele alan ve çeviri odaklı terminoloji veri tabanları veya sözlükleri üretilmesi ve geliştirilmesini amaçlayan lisansüstü tezlerin artırılması, çeviri teknolojilerinde terminoloji araçlarının öneminin ve etkisinin daha iyi anlaşılmasına olanak sağlayacaktır.

Balkul, Türkiye'deki yaygın uygulamanın aksine, anket çalışmasında akademisyenleri çalışma grubu olarak seçerek, çeviri eğitiminde akademisyenlerin görüşlerine ve teknoloji kullanımının tespitine ilişkin bulgulara ulaşmıştır: "Çeviribilim literatüründe, çeviri teknolojileriyle ilgili yapılan anket uygulamaları genelde çeviri öğrencilerini ve profesyonel çevirmenleri çalışma grubu olarak almıştır” (2015: 99). Öğrenciler ve profesyonel çevirmenlerin yanında, çalışma gruplarının öğretim elemanları ve sektörün diğer paydaşları arasından seçilmesi, verilerin karşılaştırılmasına ve daha sağlam verilere dayanan durum tespiti yapılmasına olanak sağlamaktadır. Bu yöndeki çalışmalar, çeviribilim ve çeviri teknolojileri ilişkisini kuvvetlendirerek yeni görüş, yaklaşım ve kuramların ortaya çıkmasına zemin hazırlayacaktır.

Ersoy ve Balkul (2016), çeviribilim bölümlerinde hazırlanan lisansüstü tezlerin çeviribilimin hangi araştırma alanını kapsadığını tablo halinde sunarak, tezlerin çeviribilim alanındaki konu(m)larını ortaya çıkarmıştır:

“... üzerinde durmak istediğimiz diğer bir araştırma alanı boşluğu ise, çeviri teknolojileri ve yerelleştirme alanıyla ilgilidir... Profesyonel çeviri dünyasında bu denli önem kazanan çeviri teknolojileri ve Pym (2009) tarafından çeviribilim alanında yeni bir paradigma olarak kabul edilen yerelleştirme alanında ülkemizde sadece 4 adet lisansüstü çalışmanın gerçekleştirilmesi yine üzerinde durulması gereken bir konudur" (Ersoy ve Balkul 2016: 160).

Çeviri teknolojileri, yerelleştirme konusunda yeterli düzeyde ve sayıda çalışma yapılmaması alanın gelişmesinin önünde engel teşkil etmektedir. Öztürk, tez araştırması yaparken 
konuyla ilgili yeterli sayıda ve düzeyde Türkçe kaynak bulamadığına şu sözlerle değinmiştir: "Bu çalışma sürecince karşılaşılan diğer bir önemli sorun da Türkçe dilinde alanla ilgili terminolojik eksikliğin söz konusu olmasıdır. Bu durumun sebebi de bu alanda Türkçe dilinde başvuru kaynağ olarak kullanılabilecek çalışmaların yetersizliği olarak görülmektedir” (2013: 69).

Ayrıca, makine çevirisini çeviribilim bağlamında ele alan lisansüstü çalışmalar da artırılmalıdır. Şahin, yüksek lisans tezinde, bu konudaki eksikliği şöyle aktarmaktadır:

“Buna ek olarak, çeviri teknolojileri söz konusu olduğunda, genellikle BÇA’ya yönelen çeviribilim literatüründe bilgisayar çevirisi konusunda bir boşluk yer almaktadır. Bu çalışma İngilizce ve Türkçe arasında çeviri yapan Google Translate, Proçeviri ve Sametran bilgisayar çevirisi programlarının kalitelerini değerlendirerek literatürdeki bu boşluğu doldurmayı hedeflemektedir." (2015: V)

Şahin'in tezinin İngilizce olduğu göz önünde bulundurulduğunda, bu konudaki Türkçe tez sayısının artırılması, çeviribilim literatürümüzün zenginleştirilmesi açısından önem taşımaktadır.

Çeviride dijital medya araçlarının yerini ele alan çalışmaların artırılması da alan literatürünün geliştirilmesine olumlu yönde yansıyacaktır. Türkmen'in, çeviri eğitiminde dijital medya edincini konu edinen, doktora tez çalışması, dijital medya araçlarının çeviri eğitimindeki yerinin irdelenmesi açısından diğer tez çalışmalarından ayrılmaktadır. Anket çalışması, çeviri eğitiminde, öğrencilerin, dijital medya edinci kazanmaları gerekliliğini ortaya koyarak teknolojinin farkl1 bir boyutunu ortaya koymuştur (Türkmen: 2019).

Çeviri teknolojileriyle ilgili derslerin ayrı okutulmasının yanında, çeviri teknolojilerinin diğer bazı çeviri derslerinde kullanımını kapsayan müfredat önerileri ve içerik modelleri sunan lisansüstü tez çalışmaları yapılabilir. Böylece, çeviri eğitiminde gerekli düzenlemeler yapılarak eğitim, piyasa koşullarına daha uygun hale getirilebilir.

Türkiye'de çeviribilim veya mütercim-tercümanlık bölümlerinde hazırlanmakta olan tezler arasında, 1 tane post-editing konulu teze rastlanmıştır. Bu konuda daha fazla çalışma yapılarak, Türkçe çeviribilim literatüründe konuya değin kaynak eksikliğinin giderilmesi gerekmektedir. Çeviri teknolojileri alt alanın Türkiye'de neden Avrupa'ya göre daha geç geliştiği, akademik düzlemde daha fazla sorgulanmalı ve Türkçe çeviribilim literatürümüzdeki boşluklar üzerinde daha fazla durulmalıdır. Hazırlanmakta olan lisansüstü tezlerin çeviri teknolojileri alanının farklı araştırma konularına yöneldiği görülmekle birlikte, 3 çalışmanın 2'sinin İngilizce dilinde olması, Türkçe çeviribilim literatüründe olumsuz bir gelişme olarak değerlendirilmektedir.

\section{Sonuç ve Öneriler}

$\mathrm{Bu}$ çalışmada, Türkiye'deki çeviri bölümlerinde hazırlanan çeviri teknolojileri, yerelleştirme konulu lisansüstü tezler, konu ve içerik açısından detaylı bir şekilde incelenerek, Türkçe çeviribilim literatürü bağlamında değerlendirilmiştir. Betimleyici yaklaşım çerçevesinde, dokümanların detaylı analiziyle elde edilen veriler ışığında, Türkçe çeviribilim literatüründe çeviri teknolojileri alt alanında hangi boşlukların doldurulduğu ortaya çıkarılmıştır.

Çalışmanın birinci bölümünde, Türkiye'deki mütercim-tercümanlık veya çeviribilim bölümlerinde hazırlanan ve hazırlanma aşamasında olan çeviri teknolojileri, yerelleştirme konulu tezler, YÖK Ulusal Tez Merkezi veri tabanı taranarak tespit edilmiştir. Tarama neticesinde ulaşılan, konu kapsamında hazırlanmış 16 lisansüstü tezin 9 tanesinin yüksek lisans tezi, 7 tanesinin doktora tezi olduğu ve bu tezlerin 15 'inin Türkçe dilinde hazırlandığg anlaşılmıştır. Tezlerin sadece 1 tanesi İngilizce dilindedir. Bu bulgu, Türkçe çeviri teknolojileri literatürünün geliştirilip zenginleştirilmesi yönünde bir çabaya işaret etmektedir. Konu kapsamındaki 16 lisansüstü tezin 7 tanesinin Sakarya Üniversitesi'nde yürütüldüğü ve 2014 yılından itibaren sayıs1 hızla artan toplamda 7 doktora tezinin 4 tanesinin Sakarya Üniversitesi’nde yürütüldüğü tespit edilmiştir. Bu bulgu, çeviri teknolojileri alanına ve Türkçe çeviri teknolojileri literatürüne katkı 
sunmada, Sakarya Üniversitesi’nin ülkemizde öncü konumda olduğuna işaret etmektedir. Konu kapsamında hazırlanmakta olan 3 lisansüstü tez tespit edilmiş olup bu tezlerin 2 tanesinin İngilizce dilinde, 1 tanesinin Türkçe dilinde olduğu anlaşılmıştır. Bu durum, Türkçe çeviribilim literatürüne, konu kapsamında daha önce ele alınmamış veya çok az ele alınmış konularda Türkçe kaynak sunulamaması açısından olumsuz bir gelişme olarak değerlendirilmiştir. 3 tezin 1 tanesi Sakarya Üniversitesinde, 2'sinin ülkemizde daha önce bu alanda tez çalışması yürütmemiş üniversitelerde yapılması olumlu bir gelişme olarak değerlendirilmiştir. 2014 yılından itibaren hazırlanan doktora tez sayısındaki hızlı artış ve doktora tezlerinde yerelleştirme konusunun ağılıklı işlenmesi, Türkçe çeviribilim literatüründeki boşluklarının doldurulması yönünde bir çabaya işaret etmektedir.

Çalışmanın ikinci bölümünde, konu kapsamındaki lisansüstü tezler ayrıntılı bir şekilde incelenerek, Türkçe çeviribilim literatüründe çeviri teknolojileri, yerelleştirme konusunda hangi boşlukların doldurulduğu açığa çıkarılmış ve alana sağladıkları katkı açısından bir değerlendirme yapılmıştır. İnceleme neticesinde, çeviri teknolojileri, yerelleştirme konusunun çeviribilimin uygulama ve kuramsal alanları açısından kısmen ele alındığı görülmüştür. Tezlerde, genel olarak, Türkiye'de daha önce ele alınmamış ve eksikliği duyulan konulara öncelik verilmiştir. Bu bağlamda, çeviri teknolojileri ve yerelleştirmenin çeviri eğitimindeki ve piyasasındaki konumu öğrencilerle, çevirmenlerle, sektör paydaşlarıyla yapılan anketlerle ve akademisyen görüşleriyle açığa çıkarılmıştır. Çeviri eğitiminde çeviri teknolojilerinin konumu, öğrencilere uygulanan anketlerle, müfredat analizleriyle veya akademisyen görüşleriyle ortaya çıkarılmış fakat bu konuyu ele alan tezlerde, çeviri teknolojileri derslerinin ders içeriklerine uygun işlenip işlenmediği yeterince sorgulanmamıştır. Bu bağlamda, derslerin içeriklerine uygun yürütülebilmesi için gerekli teknik koşullar (donanım ve materyal) ile uzman personelin sağlanıp sağlanmadığını araştıran çalışmalar da yapılmalıdır. Ayrıca, Türkiye'deki çeviri bölümlerinde genelde seçmeli statüde olan çeviri teknolojileriyle ilgili derslerin açılıp açılmadığı da araştırılmalıdır. Bunun yanında, çeviri teknolojilerinin çeviri eğitiminde etkin kullanımı için teknik çeviri gibi diğer bazı derslerin çeviri teknolojilerini içerecek şekilde düzenlenmesini kapsayan eğitim modeli önerileri sunan tez çalışmaları yapılması teşvik edilebilir. Bununla birlikte, çeviri teknolojileri, yerelleştirme konusunun çeviribilimin kuramsal alanı açısından ele alındığı lisansüstü tez çalışmalarının yeterli sayıda olmadığı görülmüştür. Bu yöndeki çalışmaların artırılması, çeviribilimin kuramsal alanının gelişmesine katkı sağlayacaktır. Değerlendirme neticesinde, yerelleştirmeyi çeviribilim bağlamında ele alan çalışmaların artırılması, post-editing (makine çevirisi düzeltmenliği) konusuyla ilgili Türkçe tezlerin hazırlanması, makine çevirisini çeviribilim bağlamında ele alan çalışmaların artırılması, BDÇ araçlarının üretimi ve değerlendirilmesine yönelik çalışmaların artırılması, yapay zekânın çeviri bağlamında ele alındığı çalışmaların artırılması, çeviri teknolojileri alt alanının bilişim alanıyla ilişkisini çeviribilim bağlamında ele alan çalışmaların artırılması gerektiği düşünülmektedir. Ayrıca, çeviribilimin diğer araştırma konularının çeviri teknolojileriyle ilişkisini ele alan tez çalışmalarına yönelmek de çeviribilim alanının gelişmesine katkı sağlayacaktır. Yüksek lisans ve doktora düzeyinde çeviri eğitimi veren ülkemizdeki tüm üniversitelerin çeviri teknolojileri, yerelleştirme konusunda tezler yürütmesi hem alanın gelişmesine hem de Türkçe alan literatürünün zenginleşmesine katkı sunacaktır.

Sonuç olarak, hızla gelişmekte olan çeviri teknolojileri, yerelleştirme alanında, Türkiye'deki çeviri bölümlerinde hazırlanan lisansüstü tezler, Türkçe çeviri teknolojileri literatürünün geliştirilip zenginleşmesine katkı sunmaktadır. Bununla birlikte, çeviri teknolojileri alt alanındaki yeni gelişmeleri ele alan çalışmalara yönelmek, uluslararası çeviribilim literatürüne paralel ilerlememize katkı sağlayacaktır. 


\section{Kaynakça}

Bacaksız, A. D. The Future of Translation Studies through Artificial Intelligence (Yapay Zekâ ile Çeviri Çalışmalarının Geleceği). (Hazırlanma aşamasında olan Yüksek Lisans Tezi). Atılım Üniversitesi. Ankara. (Erişim tarihi: https://tez.yok.gov.tr 28.08.2019).

Bakır, G. R. (2012). Yazılımda Yerelleştirme ve Çeviri. (Yayımlanmamış Yüksek Lisans Tezi). Sakarya Üniversitesi. Sakarya.

Balkul, H. İ. (2015). Türkiye'de Akademik Çeviri Eğitiminde Çeviri Teknolojilerinin Yerinin Sorgulanması: Müfredat Analizi ve Öğretim Elemanlarının Konuya İlişkin Görüşleri Üzerinden Bir Inceleme. (Yayımlanmamış Doktora Tezi). Sakarya Üniversitesi. Sakarya. https://doi.org/10.31464/jlere.420363.

Balkul, H. İ., Can, M. Z., Çalık, O., Gümüş A. F. (2018). Türkiye'de Çeviribilim Alanında 20132018 Yilları Arasında Hazırlanan Makaleler Üzerine Betimsel Bir Analiz. Filolojide Güncel Akademik Çalışmalar.Ankara: Gece Kitaplığ1. https://doi.org/10.31123/akil.534400

Canım, S. (2008). Türkiye'de Çeviri Bürolarında Web Sitesi Yerelleştirmeleri ve Bu Süreçte Bilgi Teknolojilerinin Kullanımı. (Yayımlanmamış Yüksek Lisans Tezi). İstanbul Üniversitesi. İstanbul.

Canım Alkan, S. (2013). Lisans Düzeyinde Çeviri Eğitiminde Teknoloji Eğitiminin Yeri. $\dot{I}$. $\ddot{U}$. Çeviribilim Dergisi, 7: 127-147.

Canım Alkan, S. (2014). Web Sitesi Yerelleştirmelerinde Bir Eyleyen Olarak Çevirmenin Konumu: Türkiye Örneği. (Yayımlanmamış Doktora Tezi). İstanbul Üniversitesi. İstanbul.

Çetin, Ö. (2009). Çeviride insan zekâsı ve yapay zekâ. (Yayımlanmamış Yüksek Lisans Tezi). Muğla Üniversitesi. Muğla.

Çetiner, C. (2015). Kırıkkale Üniversitesi İngilizce Mütercim-Tercümanlık Anabilim Dalı Öğrencilerinin Çeviri Teknolojilerine Yönelik Tutumlarının İncelenmesi. (Yayımlanmamış Yüksek Lisans Tezi). Sakarya Üniversitesi. Sakarya. https://doi.org/10.19126/suje.38758.

Çetiner, C., The Effect of Post-Editing on the Attitudes and Performance of Translation Students (Makine Çevirisi Sonrası Düzeltme İşleminin Çeviri Öğrencilerinin Tutum ve Çeviri Performanslarına Etkisi). (Hazırlanma aşamasında olan Doktora Tezi). Ankara Hacı Bayram Veli Üniversitesi. Ankara. (Erişim tarihi: https://tez.yok.gov.tr 28.08.2019), https://doi.org/10.29000/rumelide.649333.

Ersoy, H., Balkul, H. İ. (2016). Çeviribilim Alanındaki Lisansüstü Tezler Üzerine Betimleyici Bir Çalışma. International Journal of Languages' Education and Teaching. 4 (2): 151-163, https://doi.org/10.18298/ijlet.642.

Eryatmaz, S. (2017). Makine Çevirisi Değerlendirme Dinamiklerinin Çeviri Piyasasının İs Sinıflaması Bağlamında İncelenmesi İçin Bir Yöntem Önerisi. (Yayımlanmamış Doktora Tezi). İstanbul Üniversitesi. İstanbul.

Karagöz, S. (2019). Amatörler, uzmanlar, kâş̧ifler: Türkiye'de video oyun çevirileri ve yerelleştirme süreci. (Yayımlanmamış Doktora Tezi).Yıldız Teknik Üniversitesi. İstanbul.

Odacıŏglu, M. C. (2016). Çeviribilimde Yerelleştirme Paradigmasına Doğru. (Yayımlanmamış Doktora Tezi). Sakarya Üniversitesi. Sakarya.

Odacıoğlu, M. C. (2018). Çeviri Teknolojilerinin Çevirmen Adayları İçin Önemi: Kuramsal Bir Bakış. (Odacıoğlu \& Köktürk tarafından sunulan The effects of technology on translation students in academic translation teaching adlı bildirinin kısa özeti, 7th World Conference 
on Educational Sciences, (WCES-2015), 05-07 February 2015, Novotel Athens Convention Center, Athens, Greece), Atılım Üniversitesi. Ankara. https://doi.org/10.1016/j.sbspro.2015.07.349.

Özalp, A. (1995). Çeviri ortamı ve çevirmen: Bir çeviri projesi örneğinde çeviri süreci içindeki kararlar açısından çevirmenin rolü. (Yayımlanmamış Yüksek Lisans Tezi). İstanbul Üniversitesi. İstanbul. https://doi.org/10.14225/joh881.

Öztürk, E. (2013). Yerelleştirme ve Çeviri: Çeviribilimde ve Çeviri Eğitiminde Yerelleştirmenin Копити. (Yayımlanmamış Yüksek Lisans Tezi). Sakarya Üniversitesi. Sakarya.

Şahin, M. (2013). Çeviri ve Teknoloji. İzmir: İzmir Ekonomi Üniversitesi Yayınları.

Şahin, Ö. (2015). Bilgisayar Çevirisi Kalitesinin Değerlendirmesi Yöntemlerinde Tutarlılı. (Yayımlanmamış Yüksek Lisans Tezi). Hacettepe Üniversitesi. Ankara.

Şahin, Ö. Çeviri Belleklerindeki Farklı Derecelerdeki Bulanık Eşleşmelerin Çevirmenin Çabasına Etkisi (The Effect of Different Fuzzy Match Rates in the Translation Memories on the Effort of Translators). (Hazırlanma aşamasında olan Doktora Tezi). Sakarya Üniversitesi. Sakarya. (Erişim tarihi: $\quad$ https://tez.yok.gov.tr https://doi.org/10.29228/ijlet.39454.

Tok, Z. (2010). Fransızca bankacıllk terimlerinin Türkçe'ye çevirisi: Otomatik sözlük programı. (Yayımlanmamış Yüksek Lisans Tezi). Kırıkkale Üniversitesi. Kırıkkale.

Türkmen, B. (2019). Dijital medyanın çeviri eğitimindeki yeri ve dijital medya edinci önerisi. (Yayımlanmamış Doktora Tezi). Sakarya Üniversitesi. Sakarya.

Yalın, Y. (2005). Teknik Çeviri Eğitimi Kapsamında WEB Sitelerinin Yerelleştirilmesi Uygulamaları için Bir Model Önerisi. (Yayımlanmamış Yüksek Lisans Tezi). Yıldız Teknik Üniversitesi. İstanbul.

Yazar, U. (2017). Yerelleştirme Bağlamında Kullanılan Çeviri Teknolojileri (Çeviribilim Ögrencileri ve Çeviri Sektörü Örneklemlerinde). (Yayımlanmamış Doktora Tezi). Sakarya Üniversitesi. Sakarya.

Yazıc1, M. (2007). Çeviribilimde Yüksek Lisans Tezleri Üzerine Görgül Bir Araştırma. Anadolu Üniversitesi Eğitim Bilimleri Enstitüsü III. Lisansüstü Eğitim Sempozyumu. Lisans Üstü Eğitimde Sorunlar ve Çözüm Önerileri Bildiriler 17-20 Ekim 2007. https://doi.org/10.21764/maeuefd.581698.

https://tez.yok.gov.tr (Erişim Tarihi: 28.08.2019).

https://tez.yok.gov.tr/UlusalTezMerkezi/tezSorguSonucYeni.jsp (Erişim Tarihi: 28.08.2019). 